\title{
Is the policy for economic development in Alberta directed by the Alberta economic development authority?
}

\author{
Cliff Reiling, Ec.D.
}

The province of Alberta's economic development policy has shifted from rural-led policy development to a corporate-led direction creating significant changes in recent history. While positive outcomes have come about, the change has also resulted in increased bureaucracy, a rise in individualized approaches to program delivery, taxpayer dissatisfaction and a sizable financial debt. This paper traces the historical political climate and addresses the issues that have come to light as a result of this shift. The author also considers how the involvement of the Alberta Economic Development Authority - a group of business, education, community leaders and legislators tasked to recommend to government policy direction and changes - have influenced the province.

Keywords: economic development policy, Alberta Economic Development Authority, government

\section{Introduction}

The economic development policy in the Province of Alberta has changed considerably over the past thirty-five years. The 1960s saw a continuation of the 'pulpit policies' of Premier Rev. Ernest C. Manning which relied on maintaining agriculture, oil and gas and limited encouragement for lumber, coal and the new industry, tourism. The defeat of the Social Credit Government in August of 1971 by the Conservative Party signaled a major shift. From this date there was much greater influence on policy making by big business. The major change was that big business made requests and government responded with an appropriate policy. This change had many positive results but also led to the province amassing major debt as the expectations of the citizenry changed as to what the role of government was and who should pay. The change in policy often led to major growth in the bureaucracy required to run all the new programs. The prosperity changed the prevailing attitude of the population from 'we are all responsible for one another' to 'give us the money and we will do it ourselves'. The collective 'we' turned into 'me'. The perception of the electorate was that for every problem a program should be created by government to resolve it. How to pay for these programs and the cost of operating them may not have been properly planned. Did this lack of planning get the Province into financial debt, long term money losing commitments and taxpayer dissatisfaction? Would the answer come from the creation of the Alberta Economic Development Authority where business, education, community leaders and legislators were brought together to recommend to government policy direction and 
changes? These questions will be addressed in this paper.

\section{When you're hot, you're hot}

Historically, Alberta's prosperity has been dependent on international market forces for the sale of its key commodities - agricultural and, since 1947, crude oil and natural gas. Recognizing the need for some diversification and a more balanced pattern of economic growth in all regions of the province, the Government of Alberta has fostered since 1972 an environment which has encouraged the private sector to build upon the province's strengths.

The election of the Conservative Government of Premier Peter Lougheed in 1972 introduced a new form of politics to Albertans. Premier Lougheed, unlike previous leaders, was a corporate lawyer with big business experience and influence. In the past, rural Alberta held the majority of the seats and subsequently garnered much of the attention. The Conservatives led by $\mathrm{Mr}$. Lougheed ran on a platform of "New Directions for the Seventies". These "New Directions" unveiled to the public on September 6, 1974 contained, for the first time, the essence of an industrial strategy for Alberta. These strategies and related economic development policies directed the government to get involved with the private sector to promote business opportunities in Alberta. The Alberta Opportunity Corporation and the Agricultural Development Corporation were created to help small business and agricultural ventures with start-up financing. In 1971 there were 643,000 people employed in Alberta. In May, 1984 despite unemployment at about the national average, there were up to 1,111,000 employed in Alberta. This was a startling 72.8 per cent increase in the number of jobs in Alberta compared to an average increase of 34.3 per cent for all of Canada during the same period. Over the six years 1977 to 1982, Alberta's population growth, on average, was 30 per cent of the total Canada population expansion. ${ }^{1}$

Much of Alberta's economic strength was dependent upon depleting natural resources. A unique challenge for the provincial government was to ensure that the income derived from the sale of resources was equitably shared between the present and future generations. In 1976, Alberta created the Alberta Heritage Savings Trust Fund to set aside a portion of resource revenues so that future generations of Albertans could also benefit. This was commonly referred to as the 'Rainy Day Fund'.

By 1979 the Alberta economy was booming. Much of the wealth created was based on real estate and many new jobs were tied directly to the construction industry boom. However, considerable debt was amassed utilizing inflated property values as collateral. This would prove to be a major problem for both lending institutions and the Provincial Government. This economic boom period was short lived.

\footnotetext{
${ }^{1}$ White Paper, Proposals for an Industrial and Science Strategy for Albertans 1985 to 1990, July 1984, pp. 3-8, 32.
} 
In 1980 the Federal Liberal Government was re-elected. Several significant changes in the manner in which the Federal Government conducted the economic affairs of Canada ensued. A Federal presence across Canada was reinforced, power was increasingly centralized in Ottawa and wherever possible provincial authority was bypassed.

The disastrous National Energy Program (NEP) was one example of the extreme action taken by the Federal Government in its October 28, 1980 budget. The NEP was as much a revenue policy as an energy policy. It signalled a much more centralist and intrusive approach to national economic issues and planning.

Government has a responsibility to provide services which the private sector will not or cannot provide. In 1950 the total government share of the Gross National Expenditure was 22.1 per cent. By 1975, the government's (federal/provincial/municipal) share was in excess of 40 per cent and in 1982, a year of severe recession, this percentage rose to 47.3. The public sector in Canada posted a deficit every year from 1975 to 1998, in spite of significant surpluses in Alberta. By 1982 the deficit reached 5.3 per cent of Gross National Expenditure increased at the provincial level from 5.7 per cent of Gross National Expenditure in 1950 to 14.4 per cent in 1982.Federal government expenditures increased from 11.5 per cent of Gross National Expenditure in 1950 to over 16 per cent in the latter part of the seventies. Much of this can be attributed to federal debt servicing costs. ${ }^{2}$

From the time the Lougheed Government took power until Premier Lougheed's departure in 1985, the Alberta government introduced a considerable number of major economic initiatives. These included:

1972 Agriculture Development Corp.; Alberta Opportunity Corp.; significant highway/roadway improvements and expansions; international trade missions; new Marketing Division in Alberta Agriculture; hearings on prices for oil and gas; exploratory drilling incentive system; Alberta Housing Corporation.

1973 Urban Transportation Assistance; Mines Minerals Act and Petroleum Marketing Act (Provincial control on prices); Oil Sands Development Policy (Syncrude Agreement); Alberta Energy Company.

1974 Natural Gas Rebate Program; New Oil Royalty Structure and New Oil Pricing Agreement; Alberta Oil Sands Technology and Research Authority; Major Renewal and Expansion of Irrigation; Purchase of Pacific Western Airlines.

\footnotetext{
${ }^{2}$ Alberta in Canada, Strength in Diversity, A Government of Alberta Discussion Paper, 1983, pp. 22-23.
} 
1975 Forest Industry Support Program; Department of Business Development and Tourism established; loan guarantees for Alberta publishers (\$250,000 max.); Royalty Tax Credit; Cow-Calf Loan Program. ${ }^{3}$

These are examples of the early years of Alberta government actions. Others included were the Alberta Home Mortgage Corp.; Market Development Assistance Program; Alberta Industrial Land Program; Farming for the Future Research Assistance; Development of Kananaskis Country; Purchase of Canadian Government Grain Elevators in Edmonton, Calgary and Lethbridge; Purchase of 1000 Grain Hopper Cars; Native Venture Capital Company; Vencap Equities Alberta; Economic Resurgence Plan; Small Business Equity Corporation; Loan Guarantee Program and numerous others in the period from 1971 to 1980.

The policy of the Lougheed Government is best explained with the excerpt from Alberta Hansard - October 23, 1974:

"We have four supplementary goals; first to spread the growth on a balanced basis across the province - 'decentralization' - we like 'balanced economic growth. Secondly, to strengthen in this province what is truly free enterprise by strengthening the small and locally-controlled businesses in the province. Thirdly, by upgrading the skills of our citizens to create higher productivity, greater income and more job satisfaction than, frankly, comes from a lot of unskilled work. And fourthly, to capitalize upon our natural advantages in Alberta, such as being the gateway province to the north, the recreational potential of the eastern slopes, the untapped food-growing potential of the province and the assured source of supply we have for petrochemical feedstock". 4

On June 6, 1984, the Alberta Government authorized a large government loan guarantee for the Husky Oil Upgrader Project near Lloydminster. This was one of the largest projects which the government got directly involved in but as we will illustrate the trend continued.

\section{Oh! Alberta!}

With the departure of Premier Lougheed in October of 1985, Premier Don Getty became his successor. The national economic picture changed significantly at this time. The significant economic growth in Canada in the 1970s and the recession of the early 1980s saw all of the

\footnotetext{
${ }^{3}$ White Paper, Appendix B - Major and Selected Alberta Economic Initiatives 1971 to July 1984, pp. 78-90.

${ }^{4}$ White Paper, Proposals from Industries and Financial Strategy for Alberta, July 1984, Appendix A - Economic Goals, p. 73.
} 
provinces in Canada and many states in the United States get into the "can you top this" scenario. Companies made decisions regarding location based almost solely on what incentives were offered. Premier Getty and his cabinet had implemented policies promoting major diversification in forestry, tourism, technology and agricultural processing. Alberta quickly became a major partner in private sector projects, large and small.

The policy was to diversify the economy almost irrespective of the cost. Criticism of the Getty policies started in 1990, but the government policy continued as before. In a document entitled "Jobs for Albertans: Alberta's Economic Strategy" dated May of 1991, the Getty government defended its action by boasting a 95 per cent or better success rate on loan guarantees. The document points out that the use of loan guarantees, and other forms of government assistance, was necessary to encourage business investment. Guarantees were often used to leverage private sector investment by sharing some of the risk. The Alberta government's exposure was limited by ensuring that the assets pledged against the guarantee exceeded the value of the guarantee. The reason for government involvement was that the venture involves risk but was worth it in order to promote diversification. A list of the Provincial Guarantees by program shows Agriculture and food processing at \$1,606 millions; Economic Development \$721 millions; Forestry \$552 millions; Small Business \$282 millions; Other \$248 millions; Student Loans \$125 millions, with an outstanding balance as at January 15, 1991 of $\$ 3.5$ billion dollars. ${ }^{5}$

The rationale for the level of government guarantees did not convince the majority of the taxpayers when Gainers Inc. (Meat Packing etc.) with $\$ 55$ million in loan guarantees, a $\$ 6$ million loan, plus $\$ 35.8$ million in direct loans from the government's nominee and a $\$ 10$ million working capital guarantee defaulted and the government was forced to take control. Additionally, Principal Life Insurance, Magcan, Novatel and several government investment guarantees went sour. The demand from the electorate was that it was their money the government was investing and they wanted to have input into how it was used. The perception was that if the venture was successful then the company made and kept the profits, but if there was a loss it belonged to the taxpayers.

Desperate businesses soon realized that with the current value being less than half of their outstanding loans their only recourse was to turn the keys over to the lender and walk away. This became the wake-up call in Canada about the dangers of the inflated property values being collateral for major loans. Out of fairness to Premier Getty and his cabinet, money had been loaned on real estate in the boom times and when the energy, lumber, coal and gas prices dropped, and agriculture was faced with drought and low prices, decreases in transfer payments, all these factors complicated financial recovery. The provincial deficit and debt multiplied in consequence.

\footnotetext{
${ }^{5}$ Briefing Package, Jobs for Albertans, 1991, p. 5.
} 
Business and corporate failures signaled that a change in how decisions were made was required. No longer was the electorate satisfied that government policy be made in boardrooms. The public demanded a role in government pricing formulation. Government had little choice but to agree as revenues were dropping, debt was increasing, the civil service numbers were out of control and dissatisfaction with government and government services was growing. Nonrenewable resource revenues were no longer contributed to the Heritage Trust Fund and the annual income earned on over $\$ 12$ billion was being transferred from the Fund to General Revenues. It was estimated that the Heritage Fund's contribution to government operating revenues was equivalent to a 6 per cent sales tax. In spite of this, the debt continued to grow and deficit budgets became the norm. The Government had to regroup finances.

Initiated in the summer of 1991, the Toward 2000 Together process was started in order to give all of the people of Alberta an opportunity to contribute their ideas and concerns regarding the future of the province. Over 20,000 individuals and organizations requested copies of the initial discussion paper which outlined a number of major challenges facing the province. Over 3,500 questionnaires were completed and returned; 340 written and oral submissions, and seven round table discussions were organized throughout the province, plus a number of broad based strategy and consultation initiatives on a variety of issues were undertaken by the government. The next stage in Toward 2000 process was the Premier's Conference on Alberta's Economic Future in Calgary in 1992 with 550 participants. The advice from this complex process resulted in the 'Toward 2000' document. This was the first of several province wide consultative decision making processes from which a new Provincial Economic Development Policy was developed.

In December of 1992, Premier Ralph Klein won the leadership of the Alberta Conservative party. Politics in Alberta entered a new era. The Toward 2000 recommendations became a starting point which would see policy developed in Alberta scrutinized closely by other provinces of Canada and some states in the United States.

\section{Leadership by the people}

As the previous Mayor of the City of Calgary, Ralph Klein brought blue collar policies to government. His expression of 'we cannot have champagne taste on a beer drinker's budget' set the tone. Klein, previously a television reporter, had a reputation of caring what the little guy thinks. He continued his Friday afternoon tradition while Mayor of dropping into the King Eddy bar in downtown Calgary visiting with old friends, having a beer and listening to their concerns. This tradition he continues to this day.

When the Conservatives were re-elected the constituents were promised that their input would in 
fact be the basis for policy. The input from the Toward 2000 Together Economic Strategy had told government that they were to stay out of business; reduce government duplication; reduce debt; balance budgets; re-examine the need to provide direct financial assistance to individual businesses; improve the standard of education and health care; reduce internal trade barriers within Canada; encourage entrepreneurship and small business growth; ensure that the tax system and business climate attract investment; protect the environment; increase the value added to our resources and achieve greater cooperation between labor and management in the workplace. Over a period of four years the Government had gone to the electorate with the Toward 2000 Together, Creating Tomorrow, Vision 2000, Premier's Council on Science and Technology, the Local Development Initiative, Tourism 2000 and Special Places exercise. The new role for Government became to build a climate conducive to investment, wealth generation and job creation; facilitate economic development by providing services and information; support industry-led economic development; build strategic partnerships with business and communities; move away from direct financial assistance to other means such as infrastructure development and more favourable rates of taxation; set up and maintain open and participatory decisionmaking processes to develop effective solutions to social and economic issues. The plan of government was to achieve a balanced budget over a four year period starting in 1993/94 and greatly reduce the number of civil service employees. This process became known as 'Seizing Opportunity'. Much of the process which would be followed was taken from a book written in 1992, "Reinventing Government", by David Osborne and Ted Gaebler. The book argued against the hierarchical structure of most government bureaucracies. It stressed that close accountability requires close scrutiny and a minimum of bureaucratic discretion. The old system was thought to be responsible for the inaction and waste in government bureaucracy. The result was perceived to be often inflexible, costly, lumbering organizations structured by rules preventing creativity. Several departments in government including education and health care were regionalized with the express purpose being to cut costs, increase efficiency and promote innovation.

Although this wish list had few surprises for Government, the challenge became how do we address many of these issues without alienating investors in business, new or existing. The position taken by the Klein Government is that the private sector creates jobs and wealth in the Province and governments consume. So the role of government must be a facilitator of wealth creation for the province while reducing the amount government consumes. The second point was that government had to move fast. They adopted a tactic from business - if reductions are required make the maximum changes and then evaluate the impact and adjust as necessary. The concept of the slippery slope is far more damaging to morale and productivity than one radical cut. Once evaluation is completed, if the cuts went too far it is much easier to inflate the number of employees.

As the Mayor of Calgary, Klein had completely restructured the Calgary Economic Development 
Authority from an internally run organization to one which brought business and community leaders to the table to set policy, goals and objectives relating to economic development for the City. Premier Klein formed a similar organization at the Provincial level. This would become one of the most unique organizations formed to provide economic policy direction to Government.

\section{The Alberta economic development authority}

In the fall of 1994 Premier Klein announced that the Alberta Economic Development Authority had been formed with fifty people appointed to the Economic Council. The number was later increased to eighty-two, with fifteen appointed to the Board of Management. The Authority was be co-chaired by the Premier and Arthur R. Smith, Chairman, S.N.C. Partec Incorporated. This arrangement lasted until May 1, 1995 when Mr. Smith announced that since the Authority had now been set up as he had been asked to do, he would now step down. The Authority was then co-chaired by Eric P. Newell, Chairman, President and Chief Executive Officer of Syncrude, who chaired the Board of Management as well. Charlotte E. Robb, Vice-President, Canadian Imperial Bank of Commerce was to be responsible for the Economic Council; and Douglas H. Mitchell, QC, Senior Partner Howard Mackie Law Firm, President of the Calgary Chamber of Commerce and Past Commissioner of the Canadian Football League, was asked to coordinate government departmental participation in the Authority.

The mission statement of the authority is "to provide Alberta with a proactive vehicle, embracing both the public and private sectors, for the development of economic opportunities at home and abroad". 6 The Alberta Economic Development Authority brings together a broad cross-section of the private and public sectors across Alberta. Businesses large and small, municipal government and local economic development authorities and professionals, labour and postsecondary institutions are all represented.

It is a partnership between government and the business sector that is unique in Canada. The members are volunteers from many different walks of life. The Authority is a direct link and partnership between the Department of Economic Development and Alberta's business community. It helps develop priorities and proactive strategies to promote and foster increased investment and employment within Alberta.

One responsibility is to review the Department's Business Plans and submit recommendations to the Minister for amendment. The Authority reviews all Department Business Plans before they are submitted to the Standing Policy Committee of Cabinet. It makes recommendations to the Minister for his consideration on initiatives to be included in the Business Plan. The Authority

\footnotetext{
${ }^{6}$ Alberta Economic Development Authority, Activity Report 1997, p. 2.
} 
plans Ministerial foreign trade mission departure dates for a two year period. Planning incorporates analysis of mission target areas and post-mission results. Accompanying private sector delegates pay their mission costs. Foreign office locations are reviewed by the Authority with appropriate recommendations submitted to the Minister for their continuance, deletion or co-location with Canadian Embassies. A thorough review of all promotion programs is to be undertaken which includes media advertising, trade shows and public communication activities. The Economic Council will initiate or respond to Board of Management requests to inquire into and recommend action on any matter that inhibits economic development within the Province or such strategies that will promote economic growth.

The Board of Management assumed the day to day operational responsibilities for the Authority and such other shared obligations with the Department of Economic Development. Of particular note is that of the fifteen members of the Board of Management, five were Economic Development Professionals and on the Economic Council, three were Economic Development Professionals.

Seventeen Economic Council Task Committees were formed to address all of the sectors identified during the Toward 2000 Together process. The committees are: Agriculture; Education; Architecture, Construction and Engineering; Communications; Energy; Environment; Finance; Human Resources; Natural Resources; Manufacturing Value Added; Petrochemicals; Regulatory Matters; Taxation; Technology; External Trade; and Towards 2000 Together and Interprovincial Trade and Small Business.

A theme which became synonymous with the Province and a prerequisite of actions of the Authority is "The Alberta Advantage". All actions by Government and any of the bodies representing government must ensure that policy recommendations and initiatives are in fact an advantage to Albertans.

The process is that any recommendations made by the committees to the Council for ratification are then taken by the Chairman of the Authority to the Priorities Committee of Cabinet. Proposed policy changes go forward to the Agenda of the Committee of Cabinet which directs the item to one of the four Standing Policy Committees. The Standing Policy Committee study the policy in detail, make recommendations to Cabinet and Caucus for final approval. The Minister responsible implements decisions.

\section{Policy changes}

Examples of recommended changes in policy which resulted from involvement of the Authority relate to revenues, taxation (aviation fuel and machine and equipment tax), debt reduction, 
transportation, and to the Strategy on Greenhouse Gas Emissions. The Authority also helped plan the Team Alberta business mission to the Pacific Northwest and Mexico.

\section{Figure 1.}

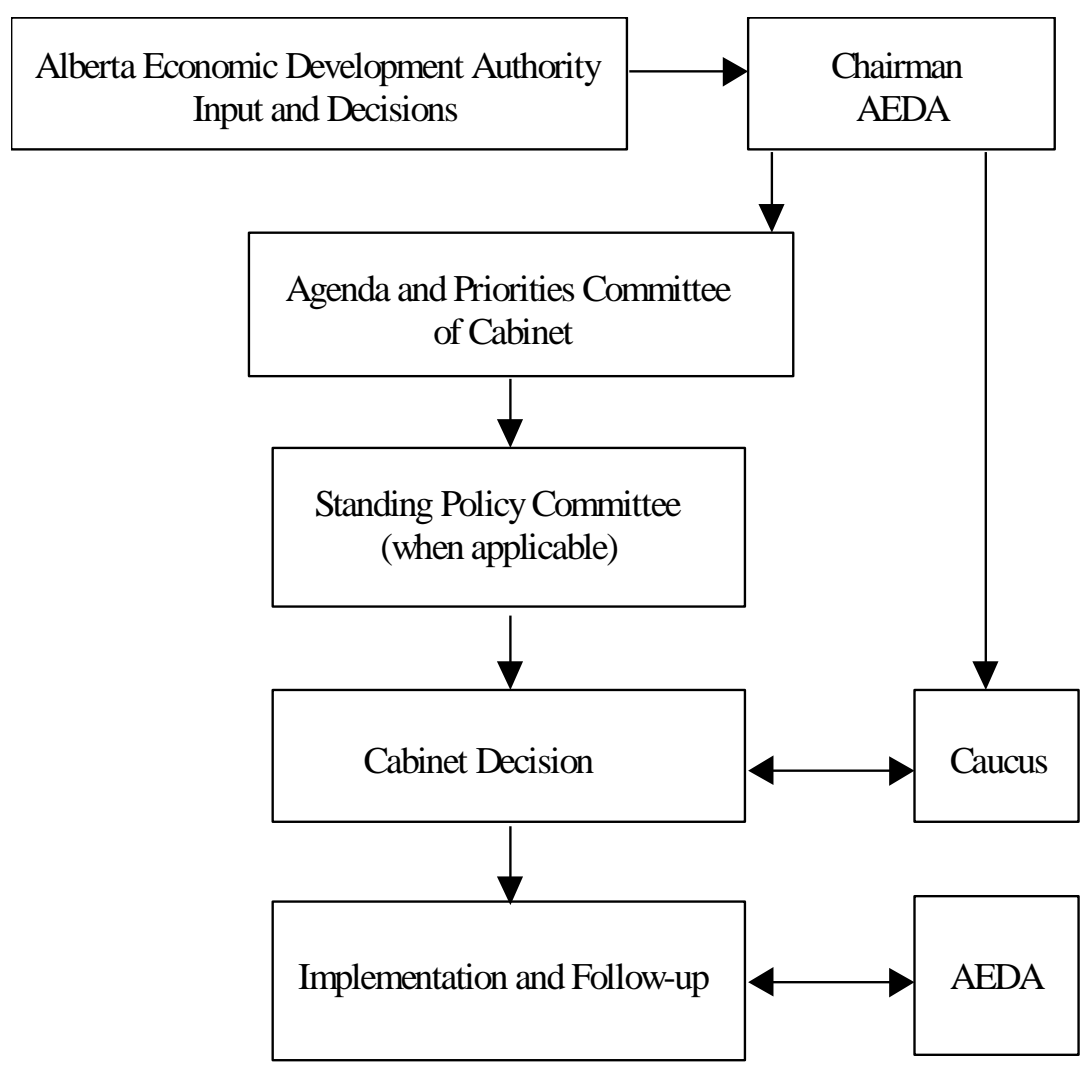

In addition, a review of successes and failures was conducted in 1996 on results achieved from recommendations of the Toward 2000 Together process held in 1992.

The major policy changes in the early 1990s saw the government implement regular performance audits to tell citizens of Alberta how they were doing. In early 1994 the Alberta Government took many of the recommendations from the Toward 2000 Together results and formulated measures which would help to achieve what people stated they wished to see happen. In December 1994, copies of a preliminary document entitled "Measuring Up" was distributed. It explained what was planned and how it was going to be measured. The feed-back basically stated that they should be clear measures of tangible results. In terms of the proposed 22 core measures for government to utilize the top five measures rated as very useful were: taxation load, employment rate, public debt per capita, crime rate and job creation. Education was sixth, water, land and air quality rated ninth, tenth and eleventh. The health status of Albertans ranked fourteenth. These processes were known as "Measuring Up - First Annual Report on the 
Performance of the Government of Alberta, June 1995; and Measuring Up - Second Annual Report on the Performance of the Government of Alberta 1995-96 Results, June 1996. This allowed the people of Alberta at a glance to rate how successful government was at getting the province's affairs in order.

In 1996, The Balanced Budget and Debt Reduction Act was introduced in response to the wishes of the people. The Act required net debt, excluding pension liabilities, to be eliminated over a 25 year period. Starting from the 1996-97 base, the province's net debt must be reduced 20 per cent by 2001-02, 40 per cent by 2006-07; 60 per cent by 2011-12, 80 per cent by 2016-17, and eliminated by $2021-22 .^{7}$

Highlights of the "Measuring Up Second Annual Report on the Performance of the Government of Alberta 1995-96" show that from 1992 the change in policy was being adhered to rigidly.

"Government has balanced the budget and started to pay down the debt. Thanks to combined spending cuts and higher than expected resource revenues and corporate taxes, the net debt was reduced from $\$ 8.71$ billion to $\$ 6.22$ billion in two years. With two years of early payment on the debt, Alberta's net debt could be eliminated in 17 years instead of 25 years as originally planned."8

By June of 1996, the forecast for elimination had moved back to 2011-12. Of note is that in 1998 the projection for elimination of net debt was the fiscal year 2005-06.

In a press release by Premier Ralph Klein on February 14, 1996 he stated:

"The real story of Alberta's success is, and will continue to be, all Albertans working together to create a quality of life second to none. Continued economic growth will be the major factor influencing Alberta's sustained prosperity.",

This marked the introduction of the 'New Economic Development Strategy - Prosperity for Albertans' process. This brought together the three co-chairs of the Authority, Members of the Legislature from the north, south and urban Alberta and the Assistant Deputy Ministers representing all government departments. This process was designed to continue to build on the 'Alberta Advantage'.

In April of 1997 'The Alberta Advantage in Action - Highlights of the Alberta Economy - the Introduction to the Alberta Advantage' was released which highlighted the many achievements

\footnotetext{
${ }^{7}$ Measuring Up, First Annual Report by the Government of Alberta, June 1995, p. 22.

${ }^{8}$ Measuring Up, Second Annual Report on the Performance of the Government of Alberta, 1995-96, June 1996, p. 30.

${ }^{9}$ Alberta Government News Release February 15, 1996, p. 1.
} 
of Government in getting their fiscal house in order. The Authority continued to help set targets for government and gave advice on how implementation could be accomplished. In some cases, interest groups stepped forward to tell government that it was time to spend or 're-invest' but the Authority encouraged government to continue on the hard road.

In 1997, the Premier Klein announced that the 'Alberta Growth Summit '97' would be held to address additional issues which had been identified in the previous public input processes. The guiding principles for the Summit were that the integrity of the existing fiscal framework will remain in place; the focus will be on creating outcomes that are sustainable; and the outcomes will reflect the principles of performance-based management. The Growth Summit delegates were organized into six sectors: agriculture and rural development; business and industry; energy; government; MASH (municipalities, academic institutions, schools and hospitals), and social economy.

The overview of the Growth Summit Process had a central theme or question which was put to the delegates,

"In the context of where we want to be in the year 2005, what are the public and private sector policies and actions needed to ensure sustainable and broad-based growth in Alberta?"10

A number of recommendations were developed by the Summit and provided to Government for future policy, and or continuation of existing policy.

Nine major issues were identified for the government to address in their new economic development policy. Highlights of the process were brought to the table of the Authority which coincided with the restructuring of the organization. The organizational structure was flattened, going from a Board of Management and Economic Council to one decision-making Board; from seventeen committees to ten; three co-chairs to one. In November of 1998, Premier Klein announced that Douglas H. Mitchell, Q.C. would become the new chair of the Alberta Economic Development Authority. The new committees would be: Agriculture and Agricultural Products; Energy and Energy Products; Tourism; Transportation and Infrastructure; Taxation and Finance; Forestry and Forestry Products; Technology and Technology Products; Export and Trade; Changing Work Place and Self-Reliant Communities.

\section{Future challenges}

The future challenges for the Authority set eight goals that reflect the current economic

${ }^{10}$ Alberta Growth Summit 1997, Business \& Industry Sector Report, September 26, 1997, p. 2. 
development priorities. The Authority would work with the provincial government on issues to help make Alberta more competitive. The goals for 1999-2000 are:

1. To ensure a globally competitive tax regime; continue efforts to remove and streamline regulations; and improve access to equity capital for businesses.

2. To ensure Alberta has a first-class infrastructure to meet the current and future needs of the economy.

3. To increase opportunities for trade and export of Alberta products and services to new and expanded markets.

4. To ensure that communities are able to build on their local strengths and resources and participate in the economic growth of the Province.

5. To develop and maintain a skilled and flexible workforce in Alberta - one that is responsive to the changing requirements of a global economy.

6. To increase the amount of Alberta's economy involved in value-added business and services.

7. To achieve sustainable economic growth that will enhance our commitment to preserve and protect Alberta's environment.

8. To ensure that Alberta is a leader in applying leading edge technology and using technology to create new products and services for markets around the world. ${ }^{11}$

All of the committees have been charged to provide direction and solutions as to how the above goals can be achieved. In addition, a committee has been established to assist in the organizing of the 1999 Global Business Forum to be held in Banff, Alberta from September 16-18, 1999. The world is constantly changing and business must continually evaluate its position to keep pace. Improving economic competitiveness is the focus of both business and government. Identifying and adopting new practices or new technologies, forming new relationships, responding to changing political and economic structures and environmental and ecological concerns are some of the challenges. The Forum will provide an excellent opportunity for the leaders in international business, and government to share their perspectives on economic strategies for the twenty-first century. The theme will be 'achieving economic prosperity through global competitiveness and leadership'. ${ }^{12}$

\footnotetext{
${ }^{11}$ Alberta Economic Development Authority, Press Release, February 1999, p. 2.

${ }^{12}$ AEDA Global Business Forum, September 16-18, 1999, p. 2.
} 
Premier Klein and his cabinet continue to follow the policy adopted when he took power. At least once yearly a major review of what is happening to keep the economy thriving and how government is helping to facilitate this activity is conducted. This process is very necessary considering that revenues for government are directly tied to world markets, which are constantly fluctuating.

How government policy was formulated in each era and the impact it had on the economy and prosperity of Albertans cannot be looked at without also investigating how the changes in policy for each government affected those directly involved in the Economic Development field. This assessment is based upon interviews with members of the Economic Development profession, Department staff and a survey of community leaders attending the Prosperity South Seminar in Medicine Hat on May 13/14, 1999. The Prosperity South organization was started in 1991 by Mayor Al Duerr with assistance from the steering group who had worked on a document 'Calgary Into the 21st. Century'. Prosperity South encouraged communities in Southern Alberta to work together and share in the many benefits of being in Southern Alberta. This has led to several initiatives including a brochure which was produced to promote activities in Southern Alberta when Calgary hosted the World Police and Fire Games in 1998. The theme for the Seminar was 'Cultivate, Activate and Collaborate'.

\section{The economic development professional}

Economic Development offices prior to 1975 were mostly located in cities. There was little rural presence. To partially alleviate this situation, in 1975 the Alberta Government established ten regional economic development offices in conjunction with communities, each having a regional board. Funding was obtained from Alberta Municipal Affairs and Alberta Economic Development and Tourism. Some local funds were raised to support the initiative.

Provincial operating funds steadily declined making the new regional economic development organizations depend more and more on local support. Additional funding was available through specific program or initiative dollars. In 1986, partially in response from more communities wanting to have an economic development function in their jurisdiction, the government did an audit on the ten projects. The results from the audit were not positive and became the basis for the government deciding to terminate the funding for the offices. The search for local funding to continue the economic development function commenced.

In late 1986, coincidental to the cuts by the Provincial Government, the Community Futures Program was announced. This program was an Adjustment Program under Employment and Immigration Canada and was intended to help communities which were suffering from major unemployment due to the downturn in the local economy and business closures. The program 
encouraged communities to develop and implement long term Community Strategic Plans leading to the sustainable development of their local economy. This job creation process allowed communities to access different federal government funding options which coincided with the needs identified in the strategic planning process.

Fortunately, when the majority of the Alberta regional economic development offices applied to this program for support they were successful. In some cases, jurisdictions were expanded to gain greater regional representation. Initially, the Community Futures Program funding included predominantly rural Alberta and smaller urban centres. Later it was expanded to include all urban centres of Alberta except for Edmonton and Calgary.

With the transfer of the Community Futures program to Industry Canada, Western Economic Diversification in 1996, the program took more of a business focus and stressed the jobs created, or maintained as a measure of success. Community development, regional cooperation and small business starts became the goal.

\section{Effects on community economic development}

The survey conducted at the Prosperity South Conference in Medicine Hat on May 13, 1999 included representatives from 42 cities, towns, communities, municipalities, municipal districts and government. Of the 57 surveys completed, 11 noted that policy related to economic development in the Province in the past six years had not impacted the delivery of the economic development function in their community. Of the 11 respondents, all were locally funded, had a limited budget, were locally administrated and were tied very closely to Mayor and Council. Four responded that their activities had increased, four stayed the same and three decreased activities. Of the 47 respondents who advised that provincial policy did impact the delivery of the economic development function, 17 responded that expenditures have increased in the past six years, 22 responded that expenditures have decreased and eight responded that the expenditures stayed the same. Of particular note, 17 of those reporting a decrease in activity were not involved with Community Futures while the remaining five were. Those who previously were directly involved with Provincial Government funding of their organizations all recorded decreases. Eleven of the respondents who stated that their budget had increased included the cities, partnerships involving Chambers of Commerce, Historical Groups, Economic Development Committees and private partnerships. Six have a direct relationship to Community Futures. The respondents noting that expenditures stayed the same indicated that five were local government funded, with their budgets frozen, while three were Community Futures related.

When questioned as to whether or not provincial policy on economic development benefits their community or area, 27 responded positively, 14 responded no, and six did not answer the 
question.

The major benefits of the Alberta Advantage initiative were reckoned by survey respondents to be: quality of life; well educated and highly skilled work force; tax structure vs. B.C. and other provinces, infrastructure; no deficit and reducing debt; no provincial sales tax; excellent hospitals, schools, post secondary institutions; volunteer base high; access to transportation systems; work ethic; Government out of the business of being in business; agriculture a priority; increased housing, manufacturing, value added and tourism; high heat unit weather; working cooperatively; ability to bring in jobs; entrepreneurial spirit high; increased awareness of our advantages internationally due to promotion; willingness to collaborate; diverse economy; economic spin-off from major growth in Calgary; low cost of living; available markets; climate; low land prices; nature, environment; clean air and water; the Rocky Mountains; world class recreation and stable government.

The survey revealed that very few economic development organizations funded entirely by local government existed. Partnerships, either within the community, area or region, were the rule.

The effects of provincial policy relating to economic development were assessed by several respondents.

Bruce A. McDonald, a Past President of the Calgary Economic Development Authority and currently the Executive Director of the Economic Developers Association of Canada, did not think the funding status of the Calgary Economic Development Authority was negatively affected by changes in Provincial policy as its funding came from the City of Calgary with some additional money from the Calgary Chamber of Commerce. The total budget remained constant over a number of years. In McDonald's view, government policy which saw numerous changes in direction and redeployment, or termination of personnel and services, was in part the result of the large number of Americans involved in the energy sector who had come from high pressure centres in the U.S. and just did things the same way once they arrived in Calgary. He noted, that 'the Legislature may have been in Edmonton but the decisions were made in Calgary'. Those decisions soon became the government policy and government scrambled to keep up with the energy sector because it was a major source of the government's revenue.

In much of rural Alberta, economic development had usually been reactive. 'Smoke stack chasing' was often a way of life. Sustainability was not in the vocabulary. The province and communities became brokers with the 'let's make a deal' philosophy. However, each time Government policy changed, a new set of rules came out and priorities changed. This was extremely difficult for those in the profession who relied on government funding for office operation and program funds to achieve results. Grantsmanship became a first priority in the 
profession.

An in-depth interview of Evan Strachan, Ec.D., Economic Development Officer, Town of Fort MacLeod, Director, Economic Developers Association of Alberta, revealed that changes in government policy had a drastic effect on his operation. The office is jointly funded by the Town on contract with the Historical Society. With a population of approximately 3,500, funds are always limited so government programs and assistance from government departments is crucial. Strachan stated that many of the policies over the years were made to address issues prevalent in the major centres. Department staffing resource cuts were usually done in the rural areas. Regionalization of government services, including education and health care had a devastating effect on many communities. "Small communities are left with the feeling that Alberta goes north to Edmonton, south to Calgary and west to Banff and Jasper - makes for a pretty small province with pretty small thinking". Many of the rural areas did not prosper in the boom years and when the fiscal belt tightening occurred, services diminished, funding dried up for local economic development initiatives, local government had to assume more functions with no additional revenue sources. 'Doing more with much less - sometimes nothing' became a common credo. Many small economic development offices saw cuts of 25 to 50 per cent in budget, and in a number of cases, the economic development function went from a professional economic developer to a volunteer committee tied to local or regional government.

With mega projects being a thing of the past, communities are now putting more emphasis on the economic development function, but usually on a regional basis. In rural Alberta, Community Futures are usually the only offices with money, resources and facilities. Duplication of provincial government services is still the major consumer of limited funds. Community development and computer data bases are being undertaken by at least three or four Provincial government departments and the Federal government at any given time but since the resource people in the communities have disappeared much gets set up which is seldom of help to those requiring it. 'Volunteerism within the communities is paramount' according the Strachan.

\section{Linda Erickson, Economic Development and Tourism Officer, County of Warner was} interviewed regarding the impact of government policy changes in her office. Linda advised that she started in this position approximately five years ago which was just the time when the Business Initiatives for Alberta Communities, Community Tourism Action Program and Management Assistance Program ended. In the small offices with very limited budgets those programs were very crucial as it allowed one to be proactive rather than reactive. In rural Alberta the major concerns are retaining small business and encouraging new ones to start stressing growing from within rather than smoke stack chasing. 'You do not have the budget to play at the table with the big centres. Unfortunately, all the attention is given to the big successes and that drives government policy'. An example used was the recent success of a large food processing 
plant where Federal, Provincial and local government officials took credit when in fact, there were a number of farmers who first approached the company, so rather than this being a successful smoke stack story it is in fact growth from within. The farmers had the raw product suitable for large-scale processing, which then made good financial sense for the company. This side of the story seldom gets told. With the change in policy which killed some of the seed funding programs it removed the leverage tool to get business/community involvement. In many cases a few thousand dollars would be enough to get other players on side in an economic development project. At the time the programs were being cut, the doing more with less era was in full swing which resulted in government cutting grants to local government which then started the local belt tightening and cuts to local economic development budgets.

Confusing the job for the local practitioner is when a department of the provincial government changes its policy it changes the focus for their staff and in our case at the regional office. Once this happens you soon see another department advertising that they are now doing those duties and all of the duplication starts except that there is no money available to the communities. There is constantly one department or organization after another starting programs which are very similar, duplication of information which then must be maintained in the small office in a half dozen different formats. There are no less than five data bases all started by different levels of government with almost identical information. This results in many non-productive hours compiling the information under different formats and a high degree of frustration because you know that you are expected to keep them all updated. All of our communities have elected volunteer politicians so when these departments/organizations send our reams of documents for the Mayor to complete; it all ends up on the same desk. They all think we have the staff of Calgary or Edmonton - its tough being a one person, part-time office. There is no end to those who get paid to help us waste our time to justify their position.

From a provincial Government Economic Development Department perspective, three interviews were conducted. The consensus was that the past twenty-five years could best be described as inconsistent provincial policies. There appeared to be agreement with the observation by Bruce McDonald that much of the policy in the seventies and eighties focussed on the energy sector and that policy was influenced by the power brokers in Calgary. Another example given of inconsistency in policy was the emphasis on rural development where programs usually had just a three time frame. The projects would collapse after three years as the communities selected were usually those with extreme needs and therefore did not have the finances to continue the initiative. The majority of the success in regional development was found in the corridor between Calgary and Edmonton because most of the local economies there were diversified. So if one sector declined, others might still prosper. There was no consistency in provincial economic development policy in terms of removing regional disparity in the respondent's opinion. 
Training in economic development taught the practitioners that economic development to be successful must be a long term process. While subscribing to this truth, government continued to start programs and cut the funding after three years. Some highly successful programs such as the Tourism Action Program, Management Assistance Program and several others were stopped even though they were achieving their purpose. In terms of recruiting businesses the fact that it usually takes a minimum of five years from the time of first contact to seeing a business start did not affect the three year cycles. Government announced in 1992/93 that many Provincial government departments would be decentralized. In excess of three hundred work out of the office in Edmonton, while in smaller centres, staff have been cut.

The inconsistency in Provincial government programs at the local level in many cases undermined the credibility of local practitioners as they were viewed as being unfocused when in fact they were constantly being forced to change direction to access money for the community. A familiar term was 'so what is the flavor of the month this time'.

There has to be much better coordination and cooperation between the Provincial Department and local economic development offices, including Community Futures. As the provincial government changes focus and drops some highly successful initiatives, Community Futures have taken on a number of those tasks. In the end, the taxpayer does not care who funds what service because they know that they pay for it, but they do want a local economic development service.

\section{Conclusion}

In Alberta the Provincial policy relating to economic development moved from rural values to those of the business community. This was triggered by the realization was that the province was on the verge of bankruptcy at the end of the Getty administration. There was major unrest within the populace. This led to the first major consultation of the electorate in the Province with the Toward 2000 Together initiative. In fact government had little choice but to listen and major policy changes happened in consequence. From the Lougheed years to the Getty years the policy had government getting into business with business. Mega projects would not progress without government involvement, either provincial, federal or sometimes both. Alberta was not the only province caught on this treadmill, all others competed using similar initiatives.

When Premier Klein took over the reins of the Alberta Conservatives he sent out the message that government would help steer the boat, but would not be responsible to row it. It was government's role to facilitate but not to control. This led to the formation of the Alberta Economic Development Authority which conducted business at the table with the leaders of the 
province. As noted previously, 'policy for the province was made in Calgary, but the legislature was in Edmonton'. No longer would government react to business with a policy, but would in fact put the mechanism in place where business could provide Government with the benefit of their particular industry knowledge. Government could then be proactive rather than reactive.

It is very evident that this policy change has been very successful. The life of the professional economic developer has become much more difficult however. Many of the programs and resources available to EDO's several years ago have disappeared. Community Futures has served to partially fill the gap created by Province of Alberta funding cutbacks for local economic development. The Program provides funding and expertise at a time when the Provincial Government was pulling out and local government could not afford to fill the gap. For greater success, Community Futures/Western Diversification and those people responsible for economic and community development must work and plan together. If this happened, and was successful, it would help forge a one tier level economic development function with sufficient funding and staffing expertise to meet the needs of communities in Alberta.

\section{Summary}

In a recent address by the Alberta Treasurer, Stockwell Day, to a life insurance underwriters' conference in Ottawa he announced that the Alberta Government had reduced the net debt to less than $\$ 500$ million from $\$ 8$ billion and will have no net debt by 2000 , and will pay off the remaining $\$ 12$ billion in debt, which is backed by provincial assets, before 2007. Mr. Day announced in his budget he intended to separate provincial taxes in Alberta from the federal tax rate by 2001 and will introduce an 11 per cent flat tax. Thus, the policy of promoting the 'Alberta Advantage' in terms of fiscal prudence continues.

The Alberta Economic Development Authority is a major player when helping to formulate the Alberta Advantage and is the major power broker in formulating the policy to ensure that the Alberta economy benefits. While not all regions and communities in Alberta benefit equally from the Alberta Advantage, it is fair to say that all will benefit once the debt is eliminated. Economic development policy in Alberta is clearly influenced substantially by the Alberta Economic Development Authority.

\section{Author's biography}

Clifford Reiling has been the Economic Development Coordinator for the Municipality of Crowsnest Pass since 1987. Prior experience includes a stint in the RCMP (1965 - 1982) and with Byron Creek Collieries (Esso Resources) (1982 -1986). He holds a Certificate and Diploma in Economic Development from the University of Waterloo Economic Development Program. 
Cliff was the Economic Developer of the Year in 1992 and received the Presidents Award of Distinction in 1997, both awards from the Economic Developers of Alberta. He was President of the Economic Developers of Alberta 1992-93. He has been a member of the Board 1988-89 to present and was a member of the Executive Committee from 1990-98. Cliff is currently a member of the Alberta Economic Development Authority.

\section{Bibliography}

Alberta Economic Development Authority. Activity Report, 1997.

Alberta Economic Development. Highlights of the Alberta Economy, 1998.

Alberta in Canada: Strength in Diversity, A Government of Alberta Discussion Paper, 1983.

Alberta Economic Development and Trade. Jobs for Albertans: Alberta's Economic Strategy., 1991.

Alberta Economic Development and Tourism. The Alberta Advantage in Action. Highlights of the Alberta Economy, April 1997.

Albertans in Business for Alberta. The Alberta Economic Development Authority, 1997.

Government of Alberta. Measuring Up. First Annual Report on the Performance of the Government of Alberta, June 1995.

Government of Alberta. Measuring Up - Second Annual Report on the Performance of the Government of Alberta: 1995 - 96 Results, June 1996.

Policy Statement \#1 In Response to the White Paper: An Industrial and Science Strategy for Albertans, 1985-1990.

Position and Policy Statement on Tourism. June, 1985.

Position and Policy Statement on Enhancing the Alberta Capital Market, September, 1985.

Policy Statement \#2 - In Response to the White Paper: An Industrial and Science Strategy for Albertans, 1985-1990.

Seizing Opportunity. Alberta’s New Economic Development Strategy, 1993. 
Reiling, Clifford. Toward 2000 Together Review. Alberta Economic Development Authority Committee Review, 1995.

Toward 2000 Together. Summary Report, May 1992.

White Paper. Proposals for an Industrial and Science Strategy for Albertans: 1985 to 1990, July 1984. 